ISTIGHNA, Vol. 2, No 1, Januari 2019 P-ISSN 1979-2824

Homepage: http://e-journal.stit-islamic-village.ac.id/index.php/istighna

Ahmad Buchori Muslim

Model Pengembangan Pendidikan Agama Islam di Perguruan Tinggi Umum

(Studi Multisitus di Universitas Brawijaya dan Universitas Negeri Malang)

\title{
MODEL PENGEMBANGAN PENDIDIKAN AGAMA ISLAM DI PERGURUAN TINGGI UMUM (Studi Multisitus di Universitas Brawijaya dan Universitas Negeri Malang)
}

\author{
Ahmad Buchori Muslim \\ (ahmadbuchori23@gmail.com) \\ Dosen Sekolah Tinggi Ilmu Tarbiyah (STIT) Islamic Village Tangerang
}

\begin{abstract}
Universities as autonomous educational institutions in the administration of education, made the development of this course will be submitted to the respective colleges. So that the implementation of the model of Islamic education among college one with the other universities are no exception can be different between the UB and the State University of Malang. Therefore in this study are the focus of research is; 1) how the Islamic education curriculum development at the UB and the State University of Malang; 2) how the learning system of Islamic education at the UB and the State University of Malang. This study uses qualitative approach, case study type with multi-site design, data analysis techniques in this study through the stages of data analysis of individual cases with the steps of data collection, data reduction, data presentation, and then draw a conclusion, after analysis of individual case data and then do the data analysis cross-site. These results indicate that the model of development of Islamic Religious Education conducted at UB and the State University of Malang is 1) the development of Islamic education curriculum using a competency-based curriculum, developed by learned center theme-based curriculum approach to social reconstruction. 2) learning system of Islamic education at both universities held in the classical cross-faculty and monitoring the deepening of learning outside the classroom with student active learning approach and contextual learning which leads to inquiry learning strategy. Generally that model of Islamic religious education at public universities can be categorized to a central model isolated entities / mechanisms and a decentralized model with interconnected entities / systemic organism.
\end{abstract}

Kata Kunci : Model Pendidikan Agama Islam, Perguruan Tinggi Umum

\section{A. Pendahuluan}

Pendidikan Agama Islam (PAI) sebagai mata kuliah pada jenjang Pendidikan Tinggi, bahwa berdasarkan Keputusan Menteri Pendidikan Nasionai Nomor 232/U/2000 tentang Pedoman Penyusuaan Kurikulum Pendidikan Tinggi dan Penilaian Hasil Belajar Mahasiswa serta Nomor 045/U/2002 tentang, Kurikulum Inti Pendidikan Tinggi telah ditetapkan bahwa Pendidikan Agama, Pendidikan Pancasila dan Pendidikan Kewarganegaraan merupakan kelompok 
ISTIGHNA, Vol. 2, No 1, Januari 2019 P-ISSN 1979-2824

Homepage: http://e-journal.stit-islamic-village.ac.id/index.php/istighna

Ahmad Buchori Muslim

Model Pengembangan Pendidikan Agama Islam di Perguruan Tinggi Umum

(Studi Multisitus di Universitas Brawijaya dan Universitas Negeri Malang)

Matakuliah Pengembangan Kepribadian (MPK) yang wajib diikuti oleh semua mahasiswa pada seluruh jurusan ${ }^{146}$.

Pendidikan Agama dalam lampiran Keputusan Menteri Pendidikan Nasional tersebut ditempatkan ke dalam kelompok Matakuliah Pengembangan Kepribadian (MPK). Sehingga terlihat jelas bagaimana pentingnya peranan Pendidikan Agama sebagai sarana pengembangan kepribadian mahasiswa dalam proses pendidikannya di Perguruan Tinggi. Melihat dari kepentingan tersebut maka sudah semestinya Pendidikan Agama (dalam hal ini Pendidikan Agama Islam) menjadi sorotan bersama bagaimana mengembangkan mata kuliah tersebut sehingga benar-benar dapat berfungsi sebagai matakuliah pengembangan kepribadian mahasiswa dan tidak hanya sebagai matakuliah pelengkap saja.

Menurut Keputusan Direktur Jenderal Pendidikan Tinggi Departemen Pendidikan Nasional Republik Indonesia Nomor: 43/Dikti/Kep/2006 tentang Rambu-Rambu Pelaksanaan Kelompok Matakuliah Pengembangan Kepribadian di Perguruan Tinggi disebutkan beberapa materi pokok yang harus terdapat di dalam perkuliahan Pendidikan Agama Islam yang diantaranya adalah menyangkut materi tentang Tuhan Yang Maha Esa dan Ketuhanan, Manusia, Hukum, Moral, Ilmu Pengetahuan, Teknologi dan Seni, Kerukunan Antar Umat Beragama, Masyarakat, Budaya, dan Politik ${ }^{147}$. Materi-materi pokok di atas kemudian dikembangkan menjadi beberapa sub pembahasan yang dapat dikembangkan oleh perguruan tinggi sesuai dengan karakteristiknya masingmasing.

Demikian itu sesuai dengan SK Dirjen Dikti tahun 2006 tentang RambuRambu Pelaksanaan Kelompok Matakuliah Pengembangan Kepribadian di Perguruan Tinggi yang terdapat pada pasal 12 menyatakan bahwa penyelenggaraan pembelajaran Matakuliah Pengembangan Kepribadian dan

146 Salinan Keputusan Menteri Pendidikan Nasional Republik Indonesia Nomor 232/U/2000 Tentang Pedoman Penyusunan Kurikulum Pendidikan Tinggi Dan Penilaian Hasil Belajar Mahasiswa

147 Salinan Keputusan Direktur Jenderal Pendidikan Tinggi Departemen Pendidikan Nasional Republik Indonesia Nomor: 43/Dikti/Kep/2006 tentang Rambu-Rambu Pelaksanaan Kelompok Matakuliah Pengembangan Kepribadian di Perguruan Tinggi Pasal 4 tentang Substansi Kajian Kelompok Matakuliah Pengembangan Kepribadian (MPK), Hlm. 3 
ISTIGHNA, Vol. 2, No 1, Januari 2019 P-ISSN 1979-2824

Homepage: http://e-journal.stit-islamic-village.ac.id/index.php/istighna

Ahmad Buchori Muslim

Model Pengembangan Pendidikan Agama Islam di Perguruan Tinggi Umum

(Studi Multisitus di Universitas Brawijaya dan Universitas Negeri Malang)

kegiatan akademik lainnya yang relevan dikelola oleh Universitas dalam satu unit bersama dengan kelompok Matakuliah Berkehidupan Bermasyarakat ${ }^{148}$. Sesuai dengan amanah pada pasal tersebut, maka dalam pengembangan matakuliah PAI secara khusus dikelola oleh dosen-dosen PAI di perguruan tinggi masing-masing sehingga tentunya akan terdapat perbedaan anatara satu perguruan tinggi dengan perguruan tinggi lainnya dalam mengembangkan mata kuliah PAI yang sesuai dengan kebutuhan dan karakteristik perguruan tinggi tersebut.

Universitas Brawijaya dan Universitas Negeri Malang merupakan representasi dari dua jenis universitas yang memiliki tujuan dan bidang keilmuan yang berbeda sehingga memungkinkan adanya perbedaan model pengembagan Pendidikan Agama Islam diantara keduanya. Universitas Brawijaya (Selanjutnya UB) merupakan sebuah universitas yang peneliti anggap sebagai representasi dari universitas dengan term keilmuan non-pendidikan atau dengan kata lain lebih kearah ilmu pengetahuan umum dan berpeluang menghasilkan ilmuan-ilmuan sains seperti fakultas Pertanian, Peternakan, Teknik, Kedokteran, serta mempersiapkan mahasiswa untuk berkarir di dunia perekonomian bisnis maupun sosial seperti fakultas Hukum, Ekonomi dan Bisnis, Ilmu Administrasi, Ilmu Sosial dan Politik, dan lain sebagainya ${ }^{149}$. Sementara itu Universitas Negeri Malang (Selanjutnya UM) merupakan representasi dari Universitas Pendidikan yang pada akhirnya melahirkan tenaga pendidik atau guru dan tenaga kependidikan dengan berbagai fakultas dan jurusannya, seperti fakultas Ilmu Pendidikan, Fakultas Sastra, Fakultas Matematika dan Ilmu Pengetahuan Alam, Fakultas Pendidikan Psikologi dan lain sebagainya. ${ }^{150}$

Berangkat dari perbedaan mendasar mengenai term keilmuan yang dikelola serta jumlah jurusan yang dikelola oleh masing-masing universitas di atas dan mengetahui jenis output yang dihasilkan oleh keduanya, maka terdapat kemungkinan adanya perbedaan terkait dengan model pengembangan Pendidikan

148 Salinan Keputusan Direktur Jenderal Pendidikan Tinggi Departemen Pendidikan Nasional Republik Indonesia Nomor: 43/Dikti/Kep/2006, Hlm. 7

${ }^{149} \mathrm{http}: / /$ www.ub.ac.id/akademik/fakultas-id, diakses pada 8 April 2015

150 http://www.um.ac.id/page/fakultas, diakses pada 8 April 2015 
ISTIGHNA, Vol. 2, No 1, Januari 2019 P-ISSN 1979-2824

Homepage: http://e-journal.stit-islamic-village.ac.id/index.php/istighna

Ahmad Buchori Muslim

Model Pengembangan Pendidikan Agama Islam di Perguruan Tinggi Umum

(Studi Multisitus di Universitas Brawijaya dan Universitas Negeri Malang)

Agama Islam sebagai Matakuliah Pengembangan Kepribadian (MPK) antara keduanya.

Maka dipandang perlu adanya model pengembangan Pendidikan Agama Islam di perguruan tinggi yang notabennya memiliki banyak jurusan dan term keilmuan. Sehingga dapat mengakomodir terhadap kebutuhan dan hubungan dengan keilmuan yang dipelajari mahasiswa. Adapun ruang lingkup yang dapat dikembangkan dalam pelaksanaan Pendidikan Agama Islam di Perguruan tinggi dapat meliputi beberapa hal, diantaranya menyangkut pengembangan kurikulum Pendidikan Agama Islam di Perguruan Tinggi dan Pengembangan sistem Pembelajaran Pendidikan Agama Islam di Perguruan Tinggi. Sehingga dengan adanya Pengembangan tersebut dapat memberikan sebuah gambaran yang utuh mengenai model Pendidikan Agama Islam di Perguruan Tinggi Umum.

Dari pengamatan sementara peneliti terhadap bentuk buku ajar yang digunakan di masing-masing Universitas, terdapat adanya berberapa perbedaan dalam pejabaran tema-tema yang telah ditentukan oleh Dirjen Dikti dalam SK Dirjen Dikti tahun 2006 tentang rambu-rambu pelaksanaan matakuliah pengembangan kepribadian. Serta terdapat beberapa pengembangan terkait dengan isu-isu kekinian seputar agama, sosial dan budaya di dalamnya. Hal ini memberikan indikasi bahwa masih terdapat beberapa faktor model pengembangan Pendidikan Agama Islam di kedua Universitas tersebut baik itu menyangkut kurikulum maupun sistem pembelajarannya.

Berdasarkan uraian dalam latar belakang di atas terkait dengan model pengembangan Pendidikan Agama Islam di Perguruan Tinggi Umum dalam hal ini di Universitas Brawijaya dan Universitas Negeri Malang sebagai objek penelitian, maka yang menjadi fokus penelitian disini adalah bagaimana model pengembangan Pendidikan Agama Islam Universitas Brawijaya dan Universitas Negeri Malang yang mencakup pengembangan kurikulum Pendidikan Agama Islam dan sistem pembelajarannya.

\section{B. Metode Penelitian}

Penelitian ini menggunakan pendekatan kualitatif, jenis studi kasus dengan rancangan multisitus, yaitu berusaha mendeskripsikan suatu latar, objek atau 
ISTIGHNA, Vol. 2, No 1, Januari 2019 P-ISSN 1979-2824

Homepage: http://e-journal.stit-islamic-village.ac.id/index.php/istighna

Ahmad Buchori Muslim

Model Pengembangan Pendidikan Agama Islam di Perguruan Tinggi Umum (Studi Multisitus di Universitas Brawijaya dan Universitas Negeri Malang)

peristiwa tertentu secara rinci dan mendalam. Studi kasus/situs adalah penelitian yang bertujuan untuk mempelajari secara intensif mengenai unit sosial tertentu, yang meliputi individu, kelompok, lembaga dan masyarakat. ${ }^{151}$ Adapun dalam penelitian ini dimaksudkan untuk dapat mengetahui pengembangan model Pendidikan Agama Islam di Universitas Negeri Malang dan Universitas Brawijaya Malang.

Sumber data dalam penelitian ini dikelompokan menjadi data primer yang diperoleh dari hasil wawancara dengan Koordinator Dosen Mata Kuliah PAI dan dosen-dosen PAI di Universitas Brawijaya Malang dan Universitas Negeri Malang mengenai fokus penelitian ini. Selain itu juga terdapat data sekunder yang peneliti peroleh dari hasil dokumentasi baik berupa teks, soft-file, maupun dokumen lain yang terkait dengan fokus penelitian di Universitas Brawijaya Malang dan Universitas Negeri Malang. ${ }^{152}$

Metode pengumpulan data yang gunakan dalam penelitian ini yaitu observasi, wawancara mendalam, dan dokumentasi. Pengecekan keabsahan data dilakukan melalui kredibilitas, dependabilitas, dan konfirmabilitas. Data-data yang telah terkumpul kemudian dianalisis dengan menggunakan teknik analisis data kasus individu dengan melalui langkah-langkah pengumpulan data, reduksi data, penyajian data dan kemudian menarik kesimpulan, setelah analisis data kasus individu selesai maka tahap selanjutnya adalah melakukan analisis data lintassitus. Secara umum proses analisis data lintas situs mencakup kegiatan sebagai berikut: a) merumuskan proposisi berdasarkan temuan situs pertama dan kemudian dilanjutkan situs kedua; b) membandingkan dan memadukan temuan teoritik sementara dari kedua situs penelitian; c) merumuskan simpulan teoritik berdasarkan analisis lintas situs sebagai temuan akhir dari kedua situs penelitian.

\section{Pembahasan dan Hasil Penelitan}

\footnotetext{
${ }^{151}$ Yatim Riyanto, Metodologi Penelitian Pendidikan, (Surabaya : SIC,2001), Hlm. 24

152 Sumadi Suryabrata, Metodologi Penelitian, (Jakarta: Raja Grafindo Persada, 1998),
} Hlm. 22 
ISTIGHNA, Vol. 2, No 1, Januari 2019 P-ISSN 1979-2824

Homepage: http://e-journal.stit-islamic-village.ac.id/index.php/istighna

Ahmad Buchori Muslim

Model Pengembangan Pendidikan Agama Islam di Perguruan Tinggi Umum

(Studi Multisitus di Universitas Brawijaya dan Universitas Negeri Malang)

Keberadaan matakuliah pendidikan agama (dalam hal ini pendidikan agama islam) sebagai bagian dari matakuliah pengembangan kepribadian yang masuk dalam kurikulum inti pendidikan tinggi, maka baik di Universitas Brawijaya maupun Universitas Negeri Malang memasukan matakuliah Pendidikan Agama Islam kedalam matakuliah wajib umum (MKWU) yang harus diambil mahasiswa disemester satu atau disemerter dua tergantung dari penjadwalan yang dilakukan setiap fakultasnya dengan beban studi sebanyak 3 sks yang dibagi ke dalam dua kegitan pendidikan agama islam.

Kegiatan pertama adalah Pendidikan Agama Islam yang termasuk matakuliah kurikuler yang dilaksanakan di dalam kelas oleh dosen-dosen PAI selama satu semester dengan beban studi sebanyak 2 sks dan kegiatan kedua adalah pelaksanaan Pendidikan Agama Islam sebagai ektrakurikuler atau kokurikuler yang dilaksanakan di luar kelas dengan beban studi sebanyak 1 sks. Sehingga meskipun dalam transkrip nilai mahasiswa ditulis beban studi matakuliah PAI sebanya 2 sks, namun dalam praktisnya secara keseluruhan adalah sebanyak 3 sks. Hal ini sebagaimana dijelaskan dalam SK DIKTI No. 43 Tahun 2006 pasal 6 ayat 2 menerangkan bahwa beban studi untuk matakuliah Pendidikan Agama, Pendidikan Kewarganegaraan, dan Bahasa masing-masing sebanyak 3 (tiga) sks (satuan kredit semester). ${ }^{153}$

Pengembangan pelaksanaan Pendidikan Agama Islam dilakukan oleh masing-masing universitas dengan tetap berdasarkan pada peraturan pemerintah yang tertera dalam perundang-undangan ataupun surat keputusan. Sebagaimana dilakukan oleh Universitas Brawijaya dan Universitas Negeri Malang adalah mengembangkan pelaksanaan Pendidikan Agama Islam yang dalam perundangundangan disebutkan beban studi matakuliah PAI tersebut adalah sebanyak 3 sks. Dengan hanya sebanyak 2 sks dalam pembelajaran PAI yang dilaksanakan di dalam kelas, maka untuk memenuhi sebanyak 3 sks dikembangkanlah sebuah kegitan penunjang pembelajaran PAI dikelas dengan kegiatan ekstrakurikuler

${ }^{153}$ Lampiran Keputusan Direktur Jenderal Pendidikan Tinggi Departemen Pendidikan Nasional Republik Indonesia Nomor: 43/Dikti/Kep/2006 tentang Rambu-rambu Pelaksanaan Kelompok Matakuliah Pengembangan Kepribadian di Perguruan Tinggi 
ISTIGHNA, Vol. 2, No 1, Januari 2019 P-ISSN 1979-2824

Homepage: http://e-journal.stit-islamic-village.ac.id/index.php/istighna

Ahmad Buchori Muslim

Model Pengembangan Pendidikan Agama Islam di Perguruan Tinggi Umum

(Studi Multisitus di Universitas Brawijaya dan Universitas Negeri Malang)

keagamaan yang dihitung sebanyak 1 sks. Sehingga tuntutan perundang-undangan yang mengharuskan beban studi Pendidikan Agama sebanyak 3 sks dapat terealisasikan. $^{154}$

Pengembangan kegitan pembelajaran PAI yang dilakukan oleh kedua situs penelitian ini dengan membuat kegitan ektrakurikuler keagamaan baik Tutorial yang dilaksanakan di Universitas Brawijaya maupun TDI (Tafaquh fii Dinil Islam) yang dilaksanakan di Universitas Negeri Malang adalah sebuah upaya pengembangan kurikulum Pendidikan Agama Islam dengan pertimbangan keterbatasan pembahasan materi-materi PAI di dalam kelas yang hanya berkisar 14 hingga 16 pertemuan dalam satu semesternya. Hal ini dirasa kurang untuk membetuk mahasiswa lulusan yang sesuai dengan amat undang-undang tentang matakuliah pengembangan kepribadian. Sehingga pihak universitas bekerjasama dengan Pusat Pembimbingan Agama Universitas (UB) dan Pusat Pengembangan Kehidupan Beragama (UM) untuk membuat sebuah kegitan keagamaan yang menunjang pembelajaran PAI di dalam kelas, sehingga diharapkan kegiatan keagamaan tersebut dapat menunjang keberhasilan pembelajaran Pendidikan Agama Islam sebagaimana dimaksud dalam perundang-undangan. ${ }^{155}$

\section{Pengembangan Kurikulum Pendidikan Agama Islam}

Pengembangan kurikulum dalam penelitian ini adalah berupa pengembangan kurikulum yang bersifat dokumen yakni terkait dengan perumusan visi dan misi serta capaian pembelajaran Pendidikan Agama Islam, dan terakhir adalah penyusunan silabus atau Rencana Perkuliahan Semester (RPS) yang dilakukan di kedua situs penelitian.

a. Perumusan Visi, Misi dan Capaian Pembelajaran Pendidikan Agama Islam

Sebuah kegitan yang terorganisir tentunya harus memiliki visi dan misi yang menjadi landasan dalam pelaksanaan semua kegitannya. Begitupun dengan Pendidikan Agama Islam di Perguruan Tinggi haruslah

${ }^{154}$ Analisis hasil wawancara dari coordinator PAI di Universitas Brawijaya dan Universitas Negeri Malang.

${ }^{155}$ Analisis hasil wawancara dari coordinator PAI, Ibid. 
ISTIGHNA, Vol. 2, No 1, Januari 2019 P-ISSN 1979-2824

Homepage: http://e-journal.stit-islamic-village.ac.id/index.php/istighna

Ahmad Buchori Muslim

Model Pengembangan Pendidikan Agama Islam di Perguruan Tinggi Umum

(Studi Multisitus di Universitas Brawijaya dan Universitas Negeri Malang)

memiliki visi dan misi tersendiri agar apa yang dilakukan memiliki dasar dan tujuan yang jelas. Oleh karenanya matakuliah Pendidikan Agama Islam yang dilaksanakan dikedua situs penelitian ini memiliki visi dan misi tersendiri dimana keduanya melakukan pengembangan perumusan visi dan misi PAI dengan mengkolaborasikan visi dan misi yang terdapat dalam perundang-undangan sebagai landasan yuridisnya dan dengan visi misi universitas masing-masing sebagai landasan praktisnya. Hal ini sebagaimana diutarakan oleh masing-masing koordinator PAI dikedua situs penelitian bahwa visi dan misi Pendidikan Agama Islam di universitasnya berdasarkan pada visi dan misi yang telah ada dalam perundang-undangan namun dengan pengembangannya disesuaikan dengan visi dan misi dari universitas masing-masing. ${ }^{156}$

Jika dilihat dari visi dan misi PAI yang dirumuskan dikedua situs penelitian, dapat ditemukan sebuah kesamaan yang substansial yakni matakuliah PAI menjadi sumber nilai dan pedoman yang mengantarkan mahasiswa dalam mengembangkan profesi dan menjadikan mahasiswa memiliki kepribadian yang Islami. ${ }^{157}$ Rumusan visi dan misi PAI baik di UB Maupun UM tersebut secara substansial menginduk pada visi misi matakuliah pengembangan kepribadian sebagaimana di jelaskan dalam SK DIKTI no 43 tahun 2006 bahwa kelompok MPK di perguruan tinggi membantu mahasiswa memantapkan kepribadiannva agar secara konsisten mampu mewujudkan nilai-nilai dasar keagamaan dan kebudayaan, rasa kebangsaan dan cinta tanah air sepanjang hayat dalam menguasai, menerapkan dan mengembangkan ilmu pengetahuan, teknologi dan seni yang dimilikinya dengan rasa tanggungjawab. ${ }^{158}$

Kemudian dari rumusan visi dan misi tersebut disusunlah capaian pembelajaran atau dapat pula dikatakan sebagai standar kompetensi

\footnotetext{
${ }^{156}$ Analisis hasil wawancara dari coordinator PAI, Op.Cit.

157 Analisis hasil wawancara dengan Koordinator PAI, Dosen PAI, dan dari dokumen di Universitas Brawijaya dan Universitas Negeri Malang.

${ }^{158}$ Lampiran Keputusan Direktur Jenderal Pendidikan Tinggi Departemen Pendidikan Nasional Republik Indonesia Nomor: 43/Dikti/Kep/2006, Op.Cit.
} 
ISTIGHNA, Vol. 2, No 1, Januari 2019 P-ISSN 1979-2824

Homepage: http://e-journal.stit-islamic-village.ac.id/index.php/istighna

Ahmad Buchori Muslim

Model Pengembangan Pendidikan Agama Islam di Perguruan Tinggi Umum

(Studi Multisitus di Universitas Brawijaya dan Universitas Negeri Malang)

matakuliah PAI. Rumusan capaian pembelajaran PAI yang dilakukan dimasing-masing situs tersebut adalah berupa poin-poin penjabaran standard minimal mahasiswa setelah mengikuti perkuliah PAI selama satu semester.

Berikut ini adalah poin-poin standar kompetensi atau capaian pembelajaran

PAI di Universitas Brawijaya dan Universitas Negeri Malang.

Tabel: Uraian Capaian Pembelajaran Pendidikan Agama Islam di Universitas

Brawijaya dan Universitas Negeri Malang T.A. 2015-2016 ${ }^{159}$

\section{Universitas Brawijaya}

Universitas Negeri Malang

1) Meningkatkan keimanan dan 1 )Meningkatkan keimanan dan

ketakwaan pada Allah SWT dalam diri

mahasiswa amelalui pemahaman, penghayatan, dan pengamalan terhadap nilai-nilai ajaran Islam.

2) Memperkokoh karakter mahasiswa melalui pemahaman, penghayatan, dan pengamalan norma-norma Islam dalam relasi yang harmonis terhadap Allah, diri sendiri, sesama umat dan lingkungannya.

3) Mengembangkan pemikiran dan akhlak mulia dalam kehidupan sebagai warga masyarakat, warga Negara, dan warga dunia.

4) Mengantarkan mahasiswa mampu bersikap rasional dan dinamis dalam mengembangkan dan memanfaatkan IPTEKS serta menjadikan ajaran Islam sebagai landasan berpikir dan berperilaku dalam pengembangan ketakwaan pada Allah SWT dalam diri mahasiswa melalui pemahaman, penghayatan, dan pengamalan terhadap nilai-nilai ajaran Islam.

2) Memperkokoh karakter mahasiswa melalui pemahaman, penghayatan, dan pengamalan norma-norma Islam dalam relasi yang harmonis terhadap Allah, diri sendiri, sesama dan lingkungannya.

3) Mengembangkan pemikiran dan akhlak yang selaras dengan keyakinan Islam dalam kehidupan sebagai warga masyarakat, warga Negara, dan warga dunia.

4) Mengantarkan mahasiswa mampu bersikap rasional dan dinamis dalam mengembangkan dan memanfaatkan IPTEKS dengan menjadikan ajaran Islam sebagai landasan berpikir dan

${ }^{159}$ Dok. Universitas Brawijaya dan Dok. Universitas Negeri Malang 
ISTIGHNA, Vol. 2, No 1, Januari 2019 P-ISSN 1979-2824

Homepage: http://e-journal.stit-islamic-village.ac.id/index.php/istighna

Ahmad Buchori Muslim

Model Pengembangan Pendidikan Agama Islam di Perguruan Tinggi Umum

(Studi Multisitus di Universitas Brawijaya dan Universitas Negeri Malang)

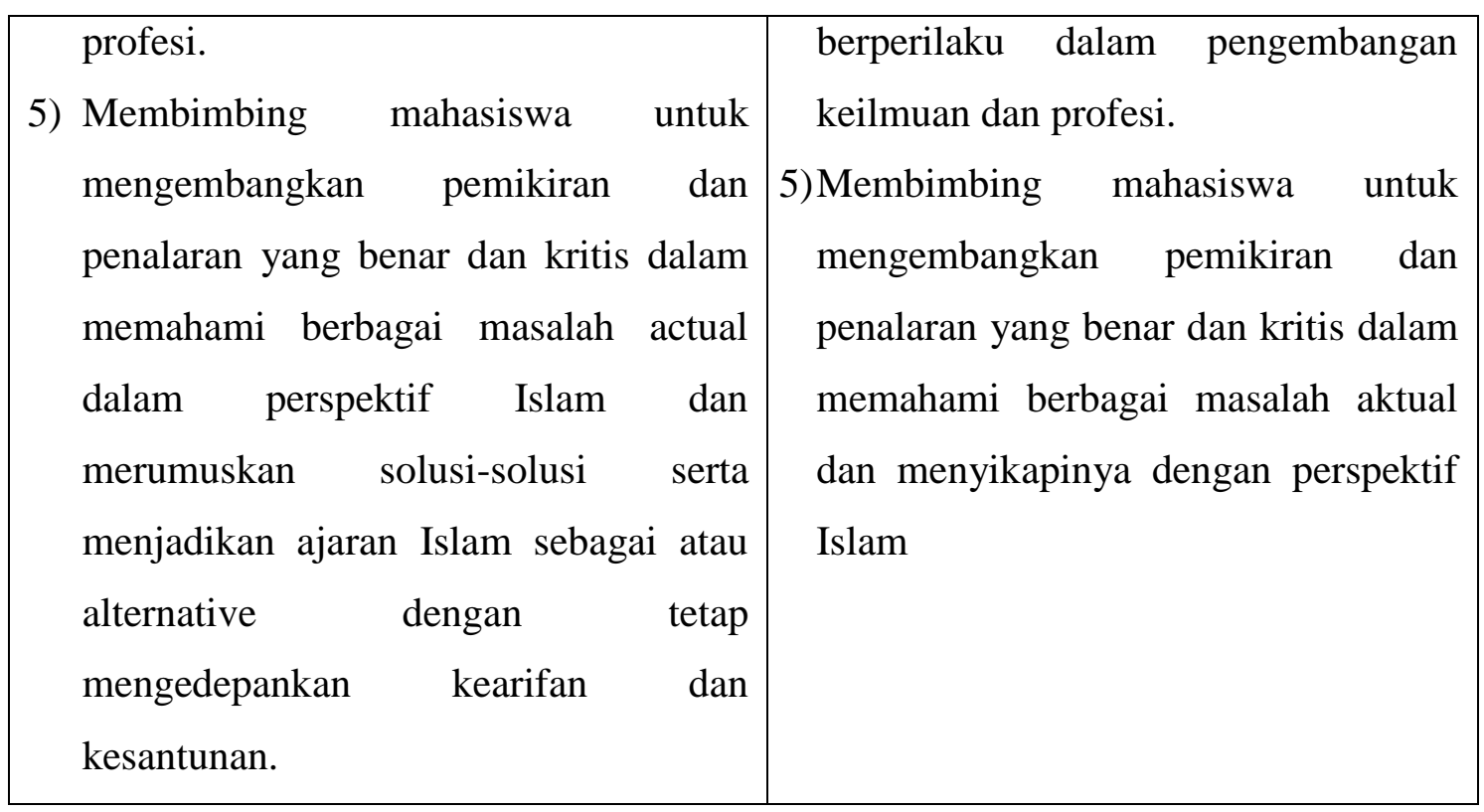

Berdasarkan pada rumusan capaian pembelajaran PAI tersebut, maka sesungguhnya pelaksanaan pembelajaran Pendidikan Agama Islam memiliki peranan yang sangat penting dalam mencetak lulusan-lulusan Perguruan Tinggi yang tidak hanya memiliki kemampuan dan keahlian dalam bidang keilmuannya atau profesinya, melainkan juga berkepribadian Islami dalam menjalankan dan mengembangkan keilmuan serta profesinya. Pernyataan ini dapat diverifikasi setidaknya dalam keputusan direktur jendral pendidikan tinggi no 43 tahun 2006 pada pasal tiga ayat 2 poin a. ${ }^{160}$

b. Penyusunan Silabus atau Rencana Perkuliahan Semester Pendidikan Agama Islam

Silabus atau dalam lingkungan perguruan tinggi dikenal sebagai Rencana Perkuliahan Semester (RPS) merupakan sebuah deskripsi matakuliah yang berisi penjabaran materi-materi identitas matakuliah, tujuan malakuliah, uraian materi. pendekatan pembelajaran, media, evaluasi hasil belajar, dan referensi yang digunakan. Keberadaan RPS tersebut

${ }^{160}$ Pasal 3 tentang Kompetensi Kelompok Matakuliah Pengembangan Kepribadian (MPK) ayat (2) Kompetensi dasar untuk masing-masing matakuliah, kemudian pada poin (a) tentang pendidikan agama ialah menjadi ilmuwan dan profesional yang beriman dan bertaqwa terhadap Tuhan Yang Maha Esa, berakhlak mulia, dan memiliki etos kerja, serta menjunjung tinggi nilainilai kemanusiaan dan kehidupan. Lampiran Keputusan Direktur Jenderal Pendidikan Tinggi Departemen Pendidikan Nasional Republik Indonesia Nomor: 43/Dikti/Kep/2006, Op.Cit. 
ISTIGHNA, Vol. 2, No 1, Januari 2019 P-ISSN 1979-2824

Homepage: http://e-journal.stit-islamic-village.ac.id/index.php/istighna

Ahmad Buchori Muslim

Model Pengembangan Pendidikan Agama Islam di Perguruan Tinggi Umum

(Studi Multisitus di Universitas Brawijaya dan Universitas Negeri Malang)

mejadi sebuah acuan pelaksanaan pembelajaran yang dilakukan di dalam kelas oleh dosen.

Dari penelitian yang sudah dilakukan di UB dan UM bahwa pelaksanaan pembelajaran PAI dikelas berpatokan pada RPS yang telah disusun dan disepakati oleh Koordinator PAI dan dosen-dosen PAI dalam rapat internal yang kemudian digunakan untuk semua fakultas dan jurusan. Semua jurusan yang mendapatkan matakuliah PAI disemesternya menggunakan RPS yang sama dengan ketentuan dosen-dosen PAI berhak melakukan pengembangan dan inovasi sendiri dari RPS yang ada, termasuk pengembangan pembelajaran PAI yang bersangkutan dengan term keilmuan mahasiswa difakultasnya.

Proses penyusunan RPS Pendidikan Agama Islam yang dilakukan oleh kedua situs penelitian tersebut sebagaimana dari hasil penelusuran peneliti baik dari hasil wawanca ataupun analisis dokumen RPS, bahwa penyusunan RPS yang dilakukan adalah berdasarkan pada substansi kajian pokok matakuliah Pendidikan Agama yang terdapat dalam SK DIKTI tahun 2006 dan kemudian dikembangkan dengan penambahan materi kajian keislaman lainnya yang berdasar atas sebuah analisis kebutuhan pembahasan persoalan-persoalan keislaman kontemporer yang terus berkembang dimasyarakat nasional maupun global. Dengan adanya pengembangan tersebut diupayakan adanya sebuah pemahaman mahasiswa tentang perkembangan dunia keislaman kontemporer yang dihadapinya sekarang atau di masa mendatang.

Bahwa setiap dosen yang mengajar PAI berusaha memberikan materimateri keislaman yang lebih mendalam terkait dengan term keilmuan mahasiswa adalah sebuah upaya pengintegrasian Agama dan Keilmuan yang dipelajari mahasiswa. Sehingga selain pembelajaran PAI tersebut dapat berjalan relative lebih menyenangkan bagi mahasiswa karena diajak berbicara materi-materi Islam dengan perspektif keilmuannya juga 
ISTIGHNA, Vol. 2, No 1, Januari 2019 P-ISSN 1979-2824

Homepage: http://e-journal.stit-islamic-village.ac.id/index.php/istighna

Ahmad Buchori Muslim

Model Pengembangan Pendidikan Agama Islam di Perguruan Tinggi Umum

(Studi Multisitus di Universitas Brawijaya dan Universitas Negeri Malang)

merupakan sebuah usaha memberikan landasan Agama bagi mahasiswa dalam mengembangkan ilmu dan profesinya kelak. ${ }^{161}$

Berdasarkan kepada uraian di atas mengenai dua aspek pengembangan kurikulum Pendidikan Agama Islam yang dilakukan oleh kedua situs penelitian tersebut, bahwa kurikulum yang digunakan adalah kurikulum berbasis kompetensi yang dikembangkan berdasarkan learned center curriculum berbasis tema-tema dengan pendekatan pengembangan kurikulum rekontruksi sosial, yakni kurikulum yang bertujuan untuk menghadapkan peserta didik pada berbagai permasalahan manusia dan kemanusiaan yang muncul dalam perjalan kehidupan. Dimana terdapat keyakinan bahwa permasalahan yang muncul tidak harus diperhatikan oleh "satu disiplin ilmu" saja, tetapi oleh setiap disiplin ilmu. ${ }^{162}$ Dan peranan dosen di sini sebagai orang yang menganjurkan perubahan (agent of change) mendorong peserta didik menjadi partisipan aktif dalam proses perbaikan masyarakat. ${ }^{163}$

Selain itu bahwa pendekatan rekonstruksi sosial sebagai pendekatan pengembangan kurikulum sangat relevan dilakukan di perguruan tinggi hal ini berdarkan pada teori pengembangan peserta didik yang pada usia mahasiswa dengan rentang usia antara 19 hingga 25 tahun merupakan masa remaja akhir yang akan masuk pada masa dewasa. Dalam masa ini menurut teori perkembangan bahwa pengembangan kognitif peserta didik telah memiliki kemampuan mengoordinasikan baik secara simultan (serentak) maupun berurutan dua ragam kemampuan kognitif, yakni; 1) kapasitas

161 Analisis hasil wawancara dengan kooodinator PAI dan Dosen PAI di Universitas Brawijaya dan Universitas Negeri Malang.

162 Oleh karena itu, pendekatan rekonstruksi sosial dalam menyusun kurikulum bertolak dari problem yang dihadapi dalam masyarakat, untuk selanjutnya dengan memerankan ilmu-ilmu dan teknologi, serta bekerja secara kooperatif dan kolaboratif, akan dicarikan upaya pemecahannya menuju pembentukan masyarakat yang lebih baik. Oemar Hamalik, Dasar-dasar Pengembangan Kurikulum (Bandung: Remaja Rosdakarya, 2007), Hlm. 146.

${ }^{163}$ Muhaimin, Pengembangan Kurikulum Pendidikan Agama Islam di Sekolah, Madrasah dan Perguruan Tinggi (Jakarta: PT RajaGrafindo Persada, 2005), Hlm. 173 
ISTIGHNA, Vol. 2, No 1, Januari 2019 P-ISSN 1979-2824

Homepage: http://e-journal.stit-islamic-village.ac.id/index.php/istighna

Ahmad Buchori Muslim

Model Pengembangan Pendidikan Agama Islam di Perguruan Tinggi Umum

(Studi Multisitus di Universitas Brawijaya dan Universitas Negeri Malang)

menggunakan hipotesis; ${ }^{164}$ 2) kapasitas menggunakan prinsip-prinsip abstrak. $^{165}$

Selanjutnya jika dilihat dari manajemen pengembangan kurikulum PAI yang dilakukan oleh kedua situs penelitian tersebut dapat dikategorikan sebagai model perpaduan antara model administratif yang berifat topdown/sentral dan model grass roots yang bersifat bottom-up/desentral. Dikatakan sebagai model administratif adalah karena dalam pengembangannya mengacu pada tujuan nasional pendidikan yang diejawantahkan melalui perundang-undangan pengembangan kurikulum pendidikan tinggi. Sebagaimana dijelaskan oleh Nana Syaodih bahwa Model pengembangan kurikulum administrative merupakan model yang paling lama dan paling banyak di kenal. Istilah lain dari model ini ialah topdown atau line-staff, karena inisiatif dan gagasan pengembangan datang dari para administrator pendidikan dan menggunakan prosedur administrasi. ${ }^{166}$

Di lain sisi bahwa pengembangan kurikulum yang dilakukan oleh kedua situs tersebut memberikan keleluasaan kepada dosen-dosen PAI untuk mengembangkannya sesuai dengan kebutuhan pembelajaran. Sebagaimana dijelaskan bahwa model grass-roots ialah dimana Inisiataif dan upaya datang dari bawah, yaitu dari guru-guru atau dosen dalam hal ini. Model grass-roots akan berkembang dalam sistem pendidikan yang bersifat desentralisasi. Oleh sebab itu, sistem pendidikan yang bersifat desentralisasi menuntut para guru/dosen untuk cerdas dan lebih kreatif dalam melaksanakan pengembangan kurikulum. Sebab guru/dosen adalah perencana, pelaksana, dan juga penyempurna dari pengajaran di kelas. ${ }^{167}$

\section{Sistem Pembelajaran Pendidikan Agama Islam}

164 Dengan kapasitas menggunakan hipotesis dalam arti dapat berpikir hipotesis, yakni berbipir sesuatu khususnya dalma pemecahan masalah dengan menggunakan anggapan dasar yang relevan dengan lingkungan yang ia respons.

165 Dengan kapasitas menggunakan prinsip-prinsip abstrak akan mampu mempelajari materi-materi pelajaran yang abstrak. Lihat Muhibbin Syah, Psikologi Belajar, (Jakarta: PT RajaGrafindo Persada, 2003), Hlm. 33-34

${ }^{166}$ Nana Syaodih, Pengembangan Kurikulum, Teori dan Praktek, (Bandung: Rasyda Karya, 2006), Hlm. 162

167 Abdullah Idi, Pengembangan Kurikulum, Teori dan Praktik (Jogjakarta: Ar-Ruzz Media, 2007), Hlm. 168, lihat juga 
ISTIGHNA, Vol. 2, No 1, Januari 2019 P-ISSN 1979-2824

Homepage: http://e-journal.stit-islamic-village.ac.id/index.php/istighna

Ahmad Buchori Muslim

Model Pengembangan Pendidikan Agama Islam di Perguruan Tinggi Umum

(Studi Multisitus di Universitas Brawijaya dan Universitas Negeri Malang)

Sistem pembelajaran adalah suatu kombinasi terorganisasi yang meliputi unsur-unsur manusiawi, material, fasilitas, perlengkapan dan prosedur yang berinteraksi untuk mencapai suatu tujuan. Unsur manusiawi dalam system pembelajaran meliputi Siwa, Guru, serta orang-orang mendukung terhadap pelaksanaan pembelajaran. Material adalah berbagai bahan pelajaran yang dapat dijadikan sebagai sumber belajar, misalnya buku, film, audio, gambar, dan sebagainya. Fasailitas dan perlengkapan adalah segala sesuatu yang dapat mendukung terhadap jalannya proses pembelajaran seperti ruang kelas, penerangan, perlengkapan computer, dan sebagainya. Prosedur adalah kegiatankegiatan yang dilakukan dalam proses pembelajaran, seperti, strategi yang digunakan, metode yang digunakan, bentuk evaluasi pembelajaran, dan sebagainya. Sebagai sebuah sistem maka kesemua komponen tersebut memiliki fungsi masing-masing dan memiliki ciri saling ketergantungan satu sama lain untuk mencapai sebuah tujuan pembelajaran. ${ }^{168}$

Pengembangan sistem pembelajaran yang dalam penelitian ini meliputi aspek pengembangan bahan ajar, pengembangan strategi pembelajaran, dan pengembangan evaluasi pembelajaran yang dilakukan di UB dan UM sebagai situs dalam penelitian ini.

a. Pengembangan Bahan Ajar Pendidikan Agama Islam

Bahan ajar adalah segala bentuk bahan yang digunakan untuk membantu guru/instruktur dalam melaksanakan proses kegiatan pembelajaran di kelas. ${ }^{169}$ Sedangkan pakar lain menerangkan bahwa yang dimaksud bahan ajar adalah seperangkat materi yang disusun secara sistematis, baik tertulis maupun tidak tertulis, sehingga tercipta lingkungan atau suasana yang memungkinkan peserta didik untuk belajar ${ }^{170}$. Selain pendapat di atas Pannen (2001) sebagaimana dikutip oleh Prastowo mendefinisakan bahan ajar adalah bahan-bahan atau materi pembelajaran

168 Wina Sanjana, Perencanaan dan Desain Sistem Pembelajaran, (Jakarta: Kencana, 2012), Hlm. 6

169 Ali Mudlofir, Aplikasi Pengembangan Kurikulum Tingkat Satuan Pendidikan dan Bahan Ajar dalam Pendidikan Agama Islam, (Jakarta: PT.Grafindo Persada, 2011), Hlm. 128

${ }^{170}$ Andi Prastowo, Panduan Kreatif Membuat Bahan Ajar Inovasi Menciptakan Metode Pembelajaran yang Menarik dan Menyenangkan, (Jogjakarta: Diva Press, 2012), Hlm. 16 
ISTIGHNA, Vol. 2, No 1, Januari 2019 P-ISSN 1979-2824

Homepage: http://e-journal.stit-islamic-village.ac.id/index.php/istighna

Ahmad Buchori Muslim

Model Pengembangan Pendidikan Agama Islam di Perguruan Tinggi Umum

(Studi Multisitus di Universitas Brawijaya dan Universitas Negeri Malang)

yang disusun secara sistematis yang digunakan oleh pendidik dan peserta didik dalam proses kegiatan belajar mengajar ${ }^{171}$

Pengembangan bahan ajar di kedua situs penelitian ini sama-sama memiliki dua bentuk bahan ajar yang digunakan selama ini. Pertama adalah bahan ajar yang berupa buku paket PAI yang disusun oleh dosen-dosen PAI sebagai buku wajib dan buku bacaan minimal mahasiswa dalam mengikuti perkuliahan Pendidikan Agama Islam. Kedua adalah bahan ajar pengembangan oleh masing-masing dosen PAI dalam pelaksanaan pembelajaran Pendidikan Agama Islam yang memiliki bentuk beragam sesuai dengan kebutuhan dan kesesuian dengan materi yang diajarkan di kelas. $^{172}$

Selanjutnya adalah berupa bahan ajar pengembangan yang dilakukan oleh masing-masing dosen dalam proses pembelajaran PAI di kelas di luar dari buku paket tersebut. Dengan adanya kebebasan dosen mengembangankan bahan ajar, hal ini menimbulkan banyak jenis bahan ajar yang kemudia digunakan dalam pembelajaran PAI sesuai dengan kebutuhan pembelajaran dosen masing-masing. Selain bahan ajar yang berbentuk teks, ada pula bahan ajar yang berbentuk audio atau audio visual, maupun media interaktif yang terdiri dari gabungan ketiga jenis bahan ajar tersebut.

Deskripsi di atas sesuai dengan apa yang dikutip oleh Mudhofir dalam Abdul Madjid, Perencanaan Pembelajaran. Mengembangkan Standar Kompetensi Guru bahwa bahan ajar harus terdiri dari beberapa prinsip diantaranya adalah Perinsip Relevansi, Prinsip Konsistensi, dan Perinsip Kecukupan. ${ }^{173}$

b. Pengembangan Strategi Pembelajaran Pendidikan Agama Islam

Strategi pembelajaran dapat diartikan sebagai perencanaan yang berisi tentang rangkaian kegiatan yang didesain untuk mencapai tujuan pendidikan tertentu. Kemp menjelaskan bahwa strategi pembelajaran adalah suatu

\footnotetext{
${ }^{171}$ Andi Prastowo, Panduan Kreatif... Hlm. 17

${ }^{172}$ Analisis hasil wawancara dari coordinator PAI, Op.Cit.

${ }^{173}$ Abdul Majid, Perencanaan Pembelajaran. Mengembangkan Standar Kompetensi Guru, (Bandung: Remaja Rosdakarya, 2006), Hlm. 187-131
} 
ISTIGHNA, Vol. 2, No 1, Januari 2019 P-ISSN 1979-2824

Homepage: http://e-journal.stit-islamic-village.ac.id/index.php/istighna

Ahmad Buchori Muslim

Model Pengembangan Pendidikan Agama Islam di Perguruan Tinggi Umum

(Studi Multisitus di Universitas Brawijaya dan Universitas Negeri Malang)

kegiatan pembelajaran yang harus dikerjakan guru dan siswa agar tujuan pembelajaran dapat dicapai secara efektif dan efisien. Senada dengan itu, Dick and Carey menyebutkan bahwa strategi pembelajaran terdiri atas seluruh komponen materi pembelajaran dan prosedur atau tahapan kegiatan belajar yang atau digunakan oleh guru dalam rangka membantu peserta didik mencapai tujuan pembelajaran tertentu. ${ }^{174}$

Dengan demikian, strategi pembelajaran merupakan cara-cara yang akan dipilih dan digunakan oleh seorang pengajar untuk menyampaikan materi pembelajaran sehingga akan memudahkan peserta didik menerima dan memahami materi pembelajaran, yang pada akhirnya tujuan pembelajaran dapat terealisasikan dengan lebih efektif dan efisien. Dalam kaitannya dengan pembelajaran PAI bahwa penentuan pendekatan pembelajaran, penggunaan metode dan media pembelajaran yang sesuai akan memberikan dampak dalam proses pelaksanaan pembelajaran itu sendiri.

Sebagaimana dari hasil penelitian yang dilakukan di UB dan UM bahwa dalam melaksanakan pembelajaran PAI dosen-dosen menggunakan pendekatan, medote dan media pembelajaran tertentu yang berbeda antara satu dosen dengan dosen yang lainnya. Meski terdapat banyak pendekatan pembelajaran yang digunakan oleh dosen-dosen PAI di kedua situs tersebut, bahwa secara substansial memiliki kesamaan yang mana pendekatan yang digunakan adalah sebuah pendekatan pembelajaran yang memaksimalkan peran mahasiswa dalam pembelajaran, seperti student active learning atau bisa juga disebut pendekatan student center learning. Dengan pendekatan pembelajaran tersebut maka dosen-dosen PAI dalam melaksakan pembelajarannya ialah dengan mengaktifkan mahasiswa, mencari, mendiskusikan, mendeskripsikan, dan kemudian mempresentasikan hasil di kelas, adalah sebuah pembelajaran yang menjadikan mahasiswa sebagai pusat pembelajaran.

${ }^{174}$ Wina Sanjaya, Strategi pembelajaran Berorientasi Standar proses Pendidikan(Cet. VII; Jakarta: Kencana, 2010), Hlm. 126 
ISTIGHNA, Vol. 2, No 1, Januari 2019 P-ISSN 1979-2824

Homepage: http://e-journal.stit-islamic-village.ac.id/index.php/istighna

Ahmad Buchori Muslim

Model Pengembangan Pendidikan Agama Islam di Perguruan Tinggi Umum

(Studi Multisitus di Universitas Brawijaya dan Universitas Negeri Malang)

Kegitan pembelajaran seperti di atas merupakan pembelajaran bersarkan prinsip student centered, peserta didik merupakan pusat dari suatu kegiatan belajar yang dikenal dengan istilah lama CBSA (cara belajar siswa aktif) sebagai terjemahan dari SAL (student active Learning), yang maknanya adalah bahwa proses pembelajaran akan lebih berhasil apabila peserta didik secara aktif melakukan latihan secara langsung dan relevan dengan tujuan pembelajaran yang sudah ditetapkan. ${ }^{175}$

Dari pendekatan pembelajaran sebagaimana diutarakan di atas, maka metode pembelajaran sudah pasti menggunakan metode-metode pembelajaran yang memberikan mahasiswa porsi lebih besar dalam pembelajaran daripada dosen. Banyak metode pembelajaran yang dapat digunakan, diantaranya adalah metode diskusi, tanya jawab, praktikum, observasi partisipatoris, dan lain sebagainya.

Berdasarkan pada hasil telaah terhadap data-data dalam penelitian ini menunjukkan penggunana metode-metode seperti di atas tersebut memang digunakan para dosen PAI dalam pembelajaran. Mulai dari metode resitasi individu maupun kelompok yang kemudian dipresentasikan dan didiskusikan di dalam kelas dengan diakhiri oleh proses Tanya jawab baik dari mahasiwa kepada mahasiswa maupun dari mahasiswa kepada dosen. Selain kegitan di kelas ada pula kegitan pembelajaran di luar kelas seperti praktikum tatacara beribadah di masjid universitas dan kegitan observasi partisipatoris dimana mahasiswa melakukan observasi lapangan ke berbagai tempat yang telah ditentukan sebelumnya untuk melakukan pembelajaran analisis social keagamaan yang terdapat ditempat observasi tersebut. ${ }^{176}$

Selain pendekatan dan metode pembelajaran, bagian terpenting lainnya adalah penggunaan media pembelajaran yang efektif merupakan sebuah keharusan agar pembelajaran menjadi menyenangkan dan memberikan pengalaman belajar menyeluruh dari yang abstrak hingga yang

175 Hamzah B. Uno, Model Pembelajaran Menciptakan Proses Belajar Mengajar Yang Kreatif Dan Efektif (Cet. IV; Jakarta: Bumi aksara, 2009), Hlm. 7

${ }^{176}$ Analisis hasil wawancara dengan Koordinator PAI, Dosen PAI, dan Observasi kelas di Universitas Brawijaya dan Universitas Negeri Malang. 
ISTIGHNA, Vol. 2, No 1, Januari 2019 P-ISSN 1979-2824

Homepage: http://e-journal.stit-islamic-village.ac.id/index.php/istighna

Ahmad Buchori Muslim

Model Pengembangan Pendidikan Agama Islam di Perguruan Tinggi Umum

(Studi Multisitus di Universitas Brawijaya dan Universitas Negeri Malang)

konkret. Media pembelajaran yang merupakan segala bentuk dan saluran yang digunakan untuk menyampaikan pesan atau informasi pembelajaran baik berbentuk orang, alat-alat elektronik/peraga, media cetak, audio, visual maupun multimedia. ${ }^{177}$

Berbagai bentuk media pembelajaran seperti di atas digunakan dalam pembelajaran PAI baik di UB maupun UM. Memaksimalkan berbagai media dalam pembelajaran PAI sangat membatu mahasiswa dalam memahami materi-materi yang di pelajari, diantaranya adalah dengan penggunaan LCD untuk presentasi, penggunaan Al-Qur'an baik cetak maupun digital untuk membaca dan mencari ayat-ayat mengenai materi yang sedang dipelajari, papan tulis, video, audio, hingga multimedia seperti yang dilakukan di Universiyas Brawijaya dengan Pusat Pembelajaran Jarak Jauh (PPJJ) yang berupa video rekaman pembelajaran PAI yang bisa di akses mahasiswa dimana saja. ${ }^{178}$

c. Pengembangan Evaluasi Pembelajaran Pendidikan Agama Islam

Evaluasi pembelajaran yang merupakan bagian terakhir dari sistem pembelajaran adalah kegiatan yang terencana untuk mengetahui keadaan objek dengan menggunakan instrument tertentu dan hasilnya dibandingkan dengan tolak ukur untuk memperoleh kesimpulan. ${ }^{179}$ Evaluasi pembelajaran yang memiliki tujuan sebagai alat untuk mengetahui keefektifan dan efesiensi sistem pembelajaran baik yang menyangkut tentang tujuan, materi, metode, media, sumber belajar, lingkungan maupun sistem penilaian itu sendiri. ${ }^{180}$

Kemudian dalam pelaksanaan pembelajaran Pendidikan Agama Islam untuk semua jenjang pendidikan tentu memiliki sistem evaluasi pembelajaran tersendiri. Pelaksanaan evaluasi pembelajaran PAI di

\footnotetext{
${ }^{177}$ Banbang Warsita, Teknologi Pembelajaran, Landasan dan aplikasinya, (Jakarta: Rineka Cipta, 2008), Hlm. 274

${ }^{178}$ Analisis hasil wawancara dengan Koordinator PAI, Dosen PAI, dan Observasi kelas di Universitas Brawijaya dan Universitas Negeri Malang.

${ }^{179}$ Ramayulis, Ilmu Pendidikan Islam, (Jakarta: Kalam Mulia, 2010), Hlm. 221

${ }^{180}$ Zainal Arifin, Evaluasi Pembelajaran, (Jakarta: DITPENDIS KEMENAG, 2012), Hlm. 
ISTIGHNA, Vol. 2, No 1, Januari 2019 P-ISSN 1979-2824

Homepage: http://e-journal.stit-islamic-village.ac.id/index.php/istighna

Ahmad Buchori Muslim

Model Pengembangan Pendidikan Agama Islam di Perguruan Tinggi Umum

(Studi Multisitus di Universitas Brawijaya dan Universitas Negeri Malang)

Perguruan Tinggi yang berupa penilaian hasil belas mahasiswa dilakukan sesuai dengan pedoman evaluasi akademik yang berlaku di Perguruan Tinggi tersebut. Sebagaimana tertera dalam SK DIKTI no 43 Tahun 2006 bahwa Penilaian hasil belajar mahasiswa dilakukan berdasarkan data yang diperoleh melalui penugasan individual atau berkelompok. ujian tengah semester. ujian akhir semester, penilaian-diri (self-assessment). penilaiansejawat (peer-assessment,), dan observasi kinerja mahasiswa melaiui tampilan lisan atau tertulis. Kriteria penilaian dan pembobotannya diserahkan kepada dosen pengampu dan disesuaikan dengan Pedoman Evaluasi Akademik yang berlaku pada perguruan tinggi masing-masing. ${ }^{181}$

Begitupun sebagaimana dilakukan oleh dosen-dosen PAI di UB dan UM, bahwa pelaksanaan evaluasi pembelajaran PAI dikategorikan ke dalam penilaian hasil belajar melalui Ujian Tengah Semester dan Ujian Akhir Semester serta penilai proses pembelajaran melalui instrument penilaian yang telah disusun. Dari kedua jenis penilaian tersebut maka pada akhirnya memberikan nilai akhir hasil pembelajaran mahasiswa. Hasil dari penelitian ini bahwa dikedua situs penelitian tersebut memiliki sedikit perbedaan mengenai kriteria penilaiannya dan kriteria kelulusan matakuliah bagi mahasiswa. Di UB kriteria kelulusan matakuliah PAI berdasarkan pada hasil akhir dari penilaian proses pembelajaran melalui instrument assessment yang telah disusun, sedangkan di UM memasukkan kompetensi membaca al-Qur'an mahasiswa sebagai persyaratan kelulusan matakuliah PAI. ${ }^{182}$

Secara keseluruhan apa yang dijelaskan di atas baik mengenai pengembangan kurikulum Pendidikan Agama Islam ataupun terkait sistem pembelajaran Pendidikan Agama Islam adalah untuk mengetahui model pengembangan Pendidikan Agama Islam yang dilakukan dikedua situs penelitian. Dari pemaparan di atas tersebut dapat ditarik sebuah kesimpulan bahwa model pengembangan Pendidikan Agama Islam yang dilakukan oleh kedua universitas

\footnotetext{
${ }^{181}$ Lampiran Keputusan Direktur Jenderal Pendidikan Tinggi Departemen Pendidikan Nasional Republik Indonesia Nomor: 43/Dikti/Kep/2006, Op.Cit.

${ }^{182}$ Analisis hasil wawancara dengan Koordinator PAI, Dosen PAI, dan Dokumen Universitas Brawijaya dan Universitas Negeri Malang.
} 
ISTIGHNA, Vol. 2, No 1, Januari 2019 P-ISSN 1979-2824

Homepage: http://e-journal.stit-islamic-village.ac.id/index.php/istighna

Ahmad Buchori Muslim

Model Pengembangan Pendidikan Agama Islam di Perguruan Tinggi Umum

(Studi Multisitus di Universitas Brawijaya dan Universitas Negeri Malang)

tersebut dapat dikategorikan menjadi dua, yakni secara sentral dan secara desentral. Secara sentral adalah model pengembangan Pendidikan Agama Islam dalam ruang lingkup perumusan visi misi, Silabus/RPS dan buku paket Pendidikan Agama Islam yang dijadikan sebagai acuan pelaksanaan Pendidikan Agama Islam oleh dosen-dosen PAI di masing-masing universitas. Sedangkan secara desentral yang dimaksud adalah sebuah model pengembangan Pendidikan Agama Islam yang dilakukan dalam kegitan praktis pembelajaran Pendidikan Agama Islam baik yang dilakukan di kelas sebagai bagian dari kurikulum inti Perguruan Tinggi maupun dalam kegiatan ekstrakurikuler keagamaan seperti kegiatan Tafaqquh fii Dinil Islam (TDI) di UM dan kegiatan Turorial keagamaan di UB.

Secara sentral model pengembangan Pendidikan Agama Islam di kedua universitas tersebut mengarah kepada model pengembangan Pendidikan Agama Islam yang dalam perspektif Amin Abdullah disebut sebagai model isolated entities dalam arti masing-masing rumpun ilmu berdiri sendiri, tahu keberadaan rumpun ilmu yang lain tetapi tidak bersentuhan dan tegur sapa. ${ }^{183}$ Sedangkan menurut Muhaimin disebut sebagai pengembangan Pendidikan Agama Islam dengan model mekanisme yang memandang kehidupan ini terdiri atas berbagai aspek, dan pendidikan dipandang sebagai penanaman dan pengembangan seperangkat nilai kehidupan, yang masing-masing bergerak dan berjalan menurut fungsinya. Aspek-aspek atau nilai-nilai kehidupan itu sendiri terdiri atas: nilai agama, nilai individu, nilai sosial, nilai politik, nilai ekonomi, nilai rasional, nilai aestetik, nilai biofisik, dan lain-lain. ${ }^{184}$ Hal ini dikarenakan oleh dengan diberlakukannya visi misi, silabus atau rencana perkuliahan semester serta buku paket PAI untuk semua fakultas dan jurusan yang tentu memiliki karakteristik keilmuan yang berbeda satu dengan yang lainnya.

${ }^{183}$ Amin Abdullah. dkk, Studi Islam dalam Paradigma Integrasi-Interkoneksi (Sebuah Antologi), (Yogyakarta: SUKA Press, 2007), Hlm. 10

${ }^{184}$ Muhaimin, Rekonstruksi Pendidikan Islam: Dari Paradigma Pengembangan, Manajemen Kelembagaan, Kurikulu Hingga Strategi Pembelajaran, (Jakarta: PT RajaGrafindo Persada, 2009), Hlm. 59-71 
ISTIGHNA, Vol. 2, No 1, Januari 2019 P-ISSN 1979-2824

Homepage: http://e-journal.stit-islamic-village.ac.id/index.php/istighna

Ahmad Buchori Muslim

Model Pengembangan Pendidikan Agama Islam di Perguruan Tinggi Umum

(Studi Multisitus di Universitas Brawijaya dan Universitas Negeri Malang)

Maka dalam hal ini bahwa model pengembangan Pendidikan Agama Islam secara sentral menjadikan Pendidikan Agama Islam sebagai sebuah disiplin ilmu tersendiri yang tidak bersentuhan secara fleksibel dengan rumpun keilmuan di setiap fakultasnya. Sehingga bahwa dengan banyaknya jurusan dengan rumpun keilmuan yang berbeda-beda, Pendidikan Agama Islam secara sentral yang meliputi visi, misi, capaian pembelajaran, silabus dan rencana perkuliahan semester, serta buku paket PAI disamakan untuk seluruh fakultas dan jurusan.

Fakta bahwa pengembangan Pendidikan Agama Islam secara sentral belum menunjukkan adanya interkoneksi atau integrasi dengan keilmuan lainnya yang terdapat sebuah perguran tinggi, maka secara desentral yang merupakan pelaksanaan pembelajaran Pendidikan Agama Islam dilapangan oleh dosen-dosen PAI baik dalam kegiatan pembelajaran di kelas maupun dalam kegiatan ekstrakurikuler terlihat adanya sebuah pengembangan Pendidikan Agama Islam kepada model interconnected entities dalam arti masing-masing keilmuan sadar akan keterbatasannya dalam memecahkan persoalan manusia, lalu menjalin kerjasama dengan disiplin keilmuan yang lain ${ }^{185}$ atau dalam istilahnya Muhaimin disebut sebagai model Organism/Sistemik yang mana pada model ini bertolak pada pandangan bahwa aktifitas kependidikan merupakan suatu sistem yang terdiri atas komponen-komponen yang hidup bersama dan bekerja sama secara terpadu menuju tujuan tertentu, yaitu terwujudnya kehidupan yang religious atau dijiwai oleh ajaran dan nilai-nilai agama. Pandangan semacam itu menggarisbawahi pentingnya kerangka pemikiran yang dibangun dari fundamental doctrines dan fundamental values yang tertuang dalam sumber ajaran pokok Islam yakni al-Qur'an dan al-Sunnah. Sehingga menempatkan nilai-nilai Agama sebagai sumber konsultasi yang bijak bagi ilmu-ilmu yang lain. ${ }^{186}$

Penjelasan di atas dalam pengamatan peneliti di kedua situs penelitian ini adalah benar adanya, karena meskipun secara visi, misi, silabus dan bahan ajar pokok berupa buku paket PAI yang digunakan sama di semua fakultas, tapi kooordinator PAI sebagai penanggungjawab pelaksanaan pendidikan agama islam

\footnotetext{
185 Amin Abdullah. dkk, Studi Islam,. Op.Cit.

${ }^{186}$ Muhaimin, Rekonstruksi Pendidikan Islam,. Op.Cit.
} 
ISTIGHNA, Vol. 2, No 1, Januari 2019 P-ISSN 1979-2824

Homepage: http://e-journal.stit-islamic-village.ac.id/index.php/istighna

Ahmad Buchori Muslim

Model Pengembangan Pendidikan Agama Islam di Perguruan Tinggi Umum

(Studi Multisitus di Universitas Brawijaya dan Universitas Negeri Malang)

di universitas memberikan keleluasaan kepada para dosen untuk mengembangkan sendiri dan berinovasi menjadikan materi-materi PAI yang diajarkan bersinggungan baik langsung maupun tidak langsung dengan keilmuan mahasiswa di fakultasnya masing-masing.

Selain itu berdasarkan dari hasil obesrvasi kelas dalam pembelajaran PAI baik di UB maupun UM para dosen dalam mengajar memberikan penekanan materi agama berkaitan dengan disiplin keilmuan mahasiswa, baik itu terlihat dari pengayaan materi yang dilakukan dalam pembelajaran maupun pemilihan langsung materi-materi yang membahas teori dari rumpun keilmuan mahasiswa dalam perspektif Islam baik al-Qur'an maupun Sunnah. Oleh sebab itu maka pengembangan Pendidikan Agama Islam secara desentral dengan model interconnected entities atau model Organism/Sistemik dapat direalisasikan dengan efektif adalah tergantung kepada kemampuan dan tingkat kreatifitas dosen yang bersangkutan. Maka tidak dipungkiri bahwa tidak semua dosen yang mengajar Pendidikan Agama Islam dapat melakukan pembelajaran Pendidikan Agama Islam dengan menggunakan model interconnected entities atau model Organism/Sistemik.

Keberadaan kegiatan ektrakurikuler keagamaan di sebuah Universitas juga memberikan sebuah pengaruh penting terealisasinya visi,misi dan tujuan pembelajaran PAI di Universitas, oleh karenanya sangat diperlukan sebuah kegiatan ekstrakurikuler sebagai penunjang pembelajaran PAI yang dilaksanakan di kelas. Hal ini selain terbatasnya waktu pembelajaran PAI di kelas yang hanya berkisar antara 14 hingga 16 kali pertemuan dalam satu semesternya juga sebagai kegitan penambah wawasan keislaman bagi mahasiswa.

Baik di UB maupun UM, keduanya menempatkan kegiatan ekstrakurikuler keagamaan sebagai bagian integral dari pembelajaran PAI di kelas, sehingga kegiatan ekstrakurikuler yang di UM dinamakan kegiatan Tafaqquh fii Dinil Islam (TDI) dan di UB dinamakan kegiatan Tutorial merupakan kegiatan wajib bagi mahasiswa yang memiliki matakuliah PAI disemesternya. Bahkan lebih jauh bahwa kegiatan ekstrakurikuler tersebut menjadi salah satu instrument penilaian 
ISTIGHNA, Vol. 2, No 1, Januari 2019 P-ISSN 1979-2824

Homepage: http://e-journal.stit-islamic-village.ac.id/index.php/istighna

Ahmad Buchori Muslim

Model Pengembangan Pendidikan Agama Islam di Perguruan Tinggi Umum

(Studi Multisitus di Universitas Brawijaya dan Universitas Negeri Malang)

yang memberikan dampak kepada hasil belajar mahasiswa dan kelulusan matakuliah PAI.

Untuk lebih memperjelas model pengembangan Pendidikan Agama Islam yang terdapat di kedua situs penelitian ini, peniliti mencoba menyusunnya dalam sebuah pemetaan seperti berikut.

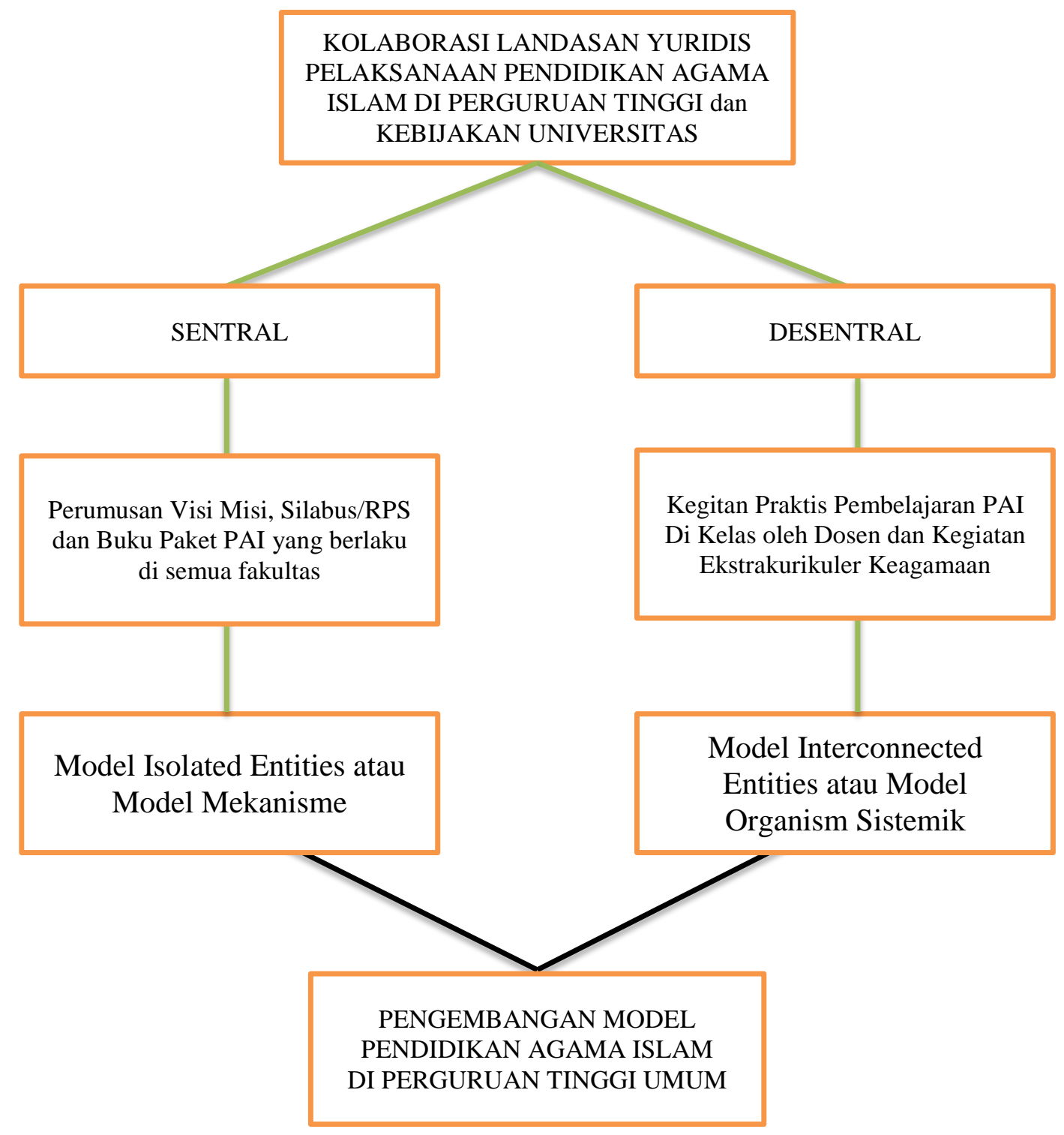

Gambar: Penjelasan Model Pengembangan Pendidikan Agama Islam di Perguruan Tinggi Umum

\section{DAFTAR RUJUKAN}


ISTIGHNA, Vol. 2, No 1, Januari 2019 P-ISSN 1979-2824

Homepage: http://e-journal.stit-islamic-village.ac.id/index.php/istighna

Ahmad Buchori Muslim

Model Pengembangan Pendidikan Agama Islam di Perguruan Tinggi Umum

(Studi Multisitus di Universitas Brawijaya dan Universitas Negeri Malang)

Abdullah. M. Amin, 2006, Islamic Studies di Perguruan Tinggi: Pendekatan Integratif-Interkonektif, Yogyakarta: Pustaka Pelajar 2002, Profil Kompetensi Akademik Lulusan Program

Pascasarjana Perguruan Tinggi Agama Islam dalam Era Masyarakat

Berubah, disampaikan dalam Pertemuan dan Konsultasi Direktur Program

Pasca Sarjana Perguruan Tinggi Agama Islam, Jakarta dkk, 2007, Studi Islam dalam Paradigma Integrasi-

Interkoneksi (Sebuah Antologi), Yogyakarta: SUKA Press

Ahmadi, Rulam, 2005, Memahami Metodologi Penelitian Kualitatif, Malang: UIN Malang Press

Al-Syaibani. Umar Muhammad al-Toumy, 1986, Al-Usus al-Nafsiyyat wa al-

Tarbiyyat li Ri'ayat al-Syabab, Kahirat: Dar Al-Ma'arif

Amri. Sofian dan Lif Khoirul Ahmadi, 2010, Kontruksi Pengembangan

Pembelajaran Pengaruhnya Terhadap Mekanisme dan Praktek Kurikulum,

Jakarrta: PT. Pustakaraya

Arikunto. Suharsimi, 2002. Prosedur Penelitian, Suatu Pendekatan Praktek.

Jakarta: Rineka Cipta

Burhan Bungin, ed., 2003, Analisis Data Penelitian Kualitatif: Pemahaman

Metodologis dan Filosofis ke Arah Model Aplikasi, Jakarta: Rraja Grafindo

Daryanto dan Herry Sudjenro, 2014, Siap Menyongsong Kurikulum 2013,

Yogyakarta: Gava Media, Yogyakarta

Faisal. Sanafiah, 1995, Format Dan Penelitian; Dasar dasar dan Aplikasi, Jakarta

: Rajawali Press , 1989, Penelitian Kualitatif: Dasar-Dasar dan Aplikasi, Malang:

Yayasan Asah, Asih, Asuh,

Golshani. Mehdi, 2004, Issues in Islam and Science, Tehran: Institute for Humanities and Cultural Studies (IHCS)

Hamalik. Oemar, 2007, Dasar-dasar Pengembangan Kurikulum, Bandung: Remaja Rosdakarya

Idi. Abdullah, 2005, Pengembangan Kurikulum, Teori dan Praktik, Jogjakarta: Ar-Ruzz Media 
ISTIGHNA, Vol. 2, No 1, Januari 2019 P-ISSN 1979-2824

Homepage: http://e-journal.stit-islamic-village.ac.id/index.php/istighna

Ahmad Buchori Muslim Model Pengembangan Pendidikan Agama Islam di Perguruan Tinggi Umum (Studi Multisitus di Universitas Brawijaya dan Universitas Negeri Malang)

2009, Rekonstruksi Pendidikan Islam: Dari Paradigma Pengembangan, Manajemen Kelembagaan, Kurikulu Hingga Strategi Pembelajaran, Jakarta: PT RajaGrafindo Persada

Lincoln, Yonna S. dan Guba, Egon G., 1985, Naturalistic Inquiry. London: Sage Publication

Moleong, Lexy J., 1991, Metodologi Penelitian Kualitatif, Bandung: PT Remaja Rosda Karya

Muhaimin, 2011, Pemikiran dan Aktualisasi Pengembangan Pendidikan Islam, Jakarta: PT. Raja Grafindo Persada , dkk. 1996, Strategi Belajar Mengajar, Surabaya: Citra Media dkk, 2008, Pengembangan Model Kurikulum Tingkat Satuan

Pendidikan (KTSP) pada Sekolah dan Madrasah, Jakarta: PT RajaGrafindo Persada 2005, Pengembangan Kurikulum Pendidikan Agama Islam di Sekolah, Madrasah dan Perguruan Tinggi, Jakarta: PT RajaGrafindo Persada

Poerwadarminta. W. J. S., 2003, Kamus Umum Bahasa Indonesia, Jakarta: Balai Pustaka

Robert. C. Bogdan, dan Sari Knopp Biklen., 1998, Qualitative Research In Education: An Introduction to Theory and Methods, Boston: Allyn and Bacon

Salinan Keputusan Menteri Pendidikan Nasional Republik Indonesia Nomor 045/U/2002 Tentang Kurikulum Inti Pendidikan Tinggi

Salinan Keputusan Menteri Pendidikan Nasional Republik Indonesia Nomor 232/U/2000 Tentang Pedoman Penyusunan Kurikulum Pendidikan Tinggi Dan Penilaian Hasil Belajar Mahasiswa

Salinan Keputusan Direktur Jenderal Pendidikan Tinggi Departemen Pendidikan Nasional Republik Indonesia Nomor: 43/Dikti/Kep/2006 tentang RambuRambu Pelaksanaan Kelompok Matakuliah Pengembangan Kepribadian di Perguruan Tinggi 
ISTIGHNA, Vol. 2, No 1, Januari 2019 P-ISSN 1979-2824

Homepage: http://e-journal.stit-islamic-village.ac.id/index.php/istighna

Ahmad Buchori Muslim

Model Pengembangan Pendidikan Agama Islam di Perguruan Tinggi Umum (Studi Multisitus di Universitas Brawijaya dan Universitas Negeri Malang)

Syaodih. Nana, 2006, Pengembangan Kurikulum, Teori dan Praktek, (Bandung: Rasyda Karya

Syahidin, dkk., 2014, Pendidikan Agama Islam Kontemporer, Jakarta: Yayasan Masyarakat Indonesia Baru

Tafsir. Ahmad, 2006, Filsafat Pendidikan Islami; Integrasi Jasmani, Rohani, dan Kalbu Memanusiakan Manusia, Bandung: PT. Remaja Rosdakarya , 2005, Ilmu Pendidikan dalam Perpektif Islam, (Bandung: Remaja

Rosdakarya

Undang-undang Republik Indonesia Nomor 14 Tahun 2005 tentang Guru dan Dosen serta Undang-undang Republik Indonesia Nomor 20 Tahun 2003 tentang Sisdiknas, Bandung: Citra Umbara

Widyastono. Herry, 2014, Pengembangan Kurikulum di Era Otonomi Daerah, Jakarta: PT.Bumi Aksara

Zuhairini dan Abdul Ghofir, 2004, Metodologi Pembelajaran Pendidikan Agama Islam, Malang: UM Press 